\title{
Modelling Transmission of Hexavalent Chromium Concentration and Its Health Cost with a Water Quality Analysis Simulation Program
}

Ying-Chu Chen ( $\nabla$ ycchen@ntut.edu.tw )

National Taipei University of Technology https://orcid.org/0000-0001-7936-0989

Chao-Heng Tseng

National Taipei University of Technology

Yun-Ting Chen

National Taipei University of Technology

\section{Research Article}

Keywords: chromium, health cost, loss of life expectancy, WASP, water

Posted Date: February 15th, 2021

DOI: https://doi.org/10.21203/rs.3.rs-180575/v1

License: (c) (i) This work is licensed under a Creative Commons Attribution 4.0 International License.

Read Full License 
Modelling Transmission of Hexavalent Chromium Concentration and Its Health

\title{
Cost with a Water Quality Analysis Simulation Program
}

$$
\text { Ying-Chu Chen }{ }^{\mathrm{a},{ }^{*}} \text {, Chao-Heng Tseng }{ }^{\mathrm{b}} \text {, Yun-Ting Chen }{ }^{\mathrm{c}}
$$

${ }^{a}$ Assistant Professor, Department of Civil Engineering, National Taipei University of Technology, Taipei City, 106, Taiwan (R.O.C.)

${ }^{\mathrm{b}}$ Professor, Institute of Environmental Engineering and Management, National Taipei University of Technology, Taipei City, 106, Taiwan (R.O.C.)

${ }^{c}$ Master of Science, Institute of Environmental Engineering and Management, National Taipei University of Technology, Taipei City, 106, Taiwan (R.O.C.)

\section{*Corresponding author: Ying-Chu Chen}

\section{E-mail: ycchen@ntut.edu.tw}

Phone: +886-2-2771-2171\#2634

Postal address: Department of Civil Engineering, National Taipei University of Technology, 1, Sec. 3, Zhongxiao E. Rd., Taipei 10608 Taiwan, R.O.C.

\begin{abstract}
In this study the Water Quality Analysis Simulation Program (WASP7) was used to evaluate the transmission of hexavalent chromium $(\mathrm{Cr}(\mathrm{VI}))$ contamination in a water-sediment system and its flux into cultivated soils. The agricultural areas adjacent to the Wu River in Taiwan were taken as the study area, as these soils were found to be heavily polluted with $\mathrm{Cr}(\mathrm{VI})$ concentrations of $3,271-16,799 \mu \mathrm{g} / \mathrm{kg}$. It was found that the rates of accumulation of $\mathrm{Cr}(\mathrm{VI})$ are affected by the distance from the source of
\end{abstract}



9 50

contamination and the size and type of cultivated areas. Specifically, maximum concentrations of $\mathrm{Cr}(\mathrm{VI})$ most rapidly accumulated in the smallest cultivated areas. The highest concentrations of $\mathrm{Cr}(\mathrm{VI})(4.27 \mathrm{mg} / \mathrm{kg})$ were detected in soil from Changhua city, and correlated with the greater risk of gastric cancer in residents from this area. Specifically, the risk of gastric cancer due to $\mathrm{Cr}(\mathrm{VI})$ contamination of agricultural soil was $3 \times 10^{-7}-15.2 \times 10^{-6}$ in Taichung city (upstream) and $1.3 \times 10^{-6}-76.3 \times$ $10^{-6}$ in Changhua county (downstream). More worryingly, young children had a threefold greater risk of gastric cancer than adults. The values of statistical life-years (VSLYs) were US\$6.2-10 million for rice, US\$42-60 million for corn, and US\$360580 million for other vegetables, respectively, each year. It is critical that techniques other than source reduction are used to reduce health costs associated with human exposure to $\mathrm{Cr}(\mathrm{VI})$, such as chemical oxidation or ion-exchange treatment to remove $\mathrm{Cr}(\mathrm{VI})$ from factory wastewaters, prior to their discharge into rivers.

Keywords: chromium; health cost; loss of life expectancy; WASP; water 1 42 3

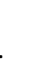
5 6 7 8 
List of Abbreviations

\begin{tabular}{|l|l|}
\hline AR & Attributable risk \\
\hline CSF & Cancer slope factor \\
\hline EPA & Environmental Protection Agency \\
\hline LADD & Lifetime average daily dose \\
\hline LLE & Loss of life expectancy \\
\hline VSLY & Value of statistical life-year \\
\hline
\end{tabular}

52

53

54

55

56

57

58

59

60

61

62

63

64

65

66

67

68

69 


\section{Introduction}

Heavy metal contamination of sediment and water is one of the greatest threats to the environment, especially the hydrological cycle (Liu et al. 2019). It was first reported in Japan in 1973 that heavy metal pollution in water and sediments of rivers could cause disease; in this case, it was mercury contamination that caused Minamata disease (Forstner and Muller 1973). Since then, there has been extensive research interest in heavy metal contamination of the environment. Such contamination of the environment depends on natural environmental and anthropogenic factors. Rivers accumulate heavy metals as they flow through areas where different anthropogenic activities are taking place, and sediments act as both carriers and sinks for contaminants (Sundaray et al. 2011). More than $97 \%$ of the mass of heavy metals transported to oceans is known to be derived from river sediments (Jain and Sharma 2001). Scientific interest in and sustainable management of agricultural areas and water have become fundamental to ensuring global food security, due to the increasing demand for agricultural and water resources (Kesstra et al. 2016; Key et al. 2016).

Intensive cultivation of land has resulted in critical problems for the agricultural economy and increasing healthcare costs (Raptis et al. 2018). The high density of electroplating factories had a potential link with high blood chromium concentrations in a sample of Taiwanese people (Chang et al. 2006a,b). A possible association between chromium and oral cancer was also identified in Taiwan (Yuan et al. 2011). Chromium exists in aqueous environments with its two stable oxidation states being $\mathrm{Cr}$ (III) and $\mathrm{Cr}(\mathrm{VI})$. They may be transformed by various physicochemical processes, such as precipitation/dissolution and adsorption and desorption reactions (Kotaś et al. 2000). In comparison, $\mathrm{Cr}(\mathrm{VI})$ is more harmful and can be generated by the oxidation of $\mathrm{Cr}(\mathrm{III})$ during chemical processes (Pradhan et al. 2017). 

rivers and gastric cancer (Tseng et al. 2018 \& 2019). High concentrations of Cr(VI) in plants have also been shown to induce changes in their physiology and morphology, and $\mathrm{Cr}(\mathrm{VI})$ has been identified as a potential carcinogen in human and animal studies (Haney et al. 2014). Taiwan established a maximum total chromium contaminant concentration of $50 \mu \mathrm{g} / \mathrm{L}$; in contrast the U.S. EPA extends limits of $100 \mu \mathrm{g} / \mathrm{L}$ (U.S. EPA 2003). General public may ingest water and/or food contaminated with $\mathrm{Cr}(\mathrm{VI})$. Exposure to chromium has been determined to have severe ill effects on health, including gastric and lung carcinoma (Zhang and Li 1997); liver, kidney, and urinary dysfunction (Linos et al. 2011); and eye and skin irritations (Costa 2003; Mohanty et al. 2005). It has been reported that reducing discharge of $\mathrm{Cr}(\mathrm{VI})$ into the environment may minimize risks to human health (Akinremi et al. 2000; Gustafsson et al. 2014; Keesstra et al. 2016).

The speciation of chromium in water and sediment and its subsequent passage into the environment has been investigated (Chow et al. 2018). The water-sediment system generates different mixing conditions, leading to an oxygenated medium that favors the formation of $\mathrm{Cr}(\mathrm{VI})$ (Kotaś and Stasicka 2000). Furthermore, sediments with negatively charged clay minerals predominate in water-sediment systems, and thus $\mathrm{Cr}(\mathrm{VI})$ cations are repelled by these soil particles, resulting in $\mathrm{Cr}(\mathrm{VI})$ being more mobile and consequently more bioavailable than $\mathrm{Cr}$ (III) in the water-sediment system (Unceta et al. 2010). The concentration of total chromium in rivers and lakes is usually 0.5 to 100

117 to sediment settling (Ghrefat and Yusuf 2006). to investigate $\mathrm{Cr}(\mathrm{VI})$ contamination in the Wu River watershed in Taiwan, extending 
our previous research (Tseng et al. 2018 \& 2019) to delineate the transmission of $\mathrm{Cr}(\mathrm{VI})$ contamination in a water-sediment system and its flux into cultivated soils. The WASP program has been applied in the development of watershed management strategies in many studies (Lin et al. 2011). For example, it was used to show that sediments in the Saltwater River watershed in southern Taiwan were polluted by chromium and other heavy metals (Liu et al. 2011). The WASP has also been widely used to simulate toxicant concentrations in surface waters and sediments over a range of complexities and temporal and spatial scales (Knightes et al. 2019). The health risks associated with $\mathrm{Cr}(\mathrm{VI})$ contamination of cultivated soils have been monetized into loss of life expectancy (LLE). In turn, this allows evaluation of the capability of different types of wastewater treatment plants to remove $\mathrm{Cr}(\mathrm{VI})$ contamination.

\section{Materials and Methods}

\subsection{System boundaries used in this study}

As shown in Fig. 1, the Wu River is $119 \mathrm{~km}$ long and enters the area in Taichung city (upstream) and flows into irrigation channels in Changhua county (downstream). The watershed belongs to the fourth largest river in Taiwan in terms of drainage area. The agricultural areas in Changhua city (marked as "C") and Homei district ("H") in Changhua county are heavily polluted by heavy metals, including $\mathrm{Cr}(\mathrm{VI})$, and are irrigated mostly with water drawn from the $\mathrm{Wu}$ River watershed. The Dali district (marked as "D") and Wufen district (marked as "W") in Taichung city contain many factories, which are source of pollutants. Rice cultivation in Changhua county accounts for $18-20 \%$ of national rice production, and is therefore a key to food supply in Taiwan. The effects of $\mathrm{Cr}(\mathrm{VI})$ on rice, corn and vegetable cultivation are compared, as these may lead to different health risks. 
Figure 1 here.

\subsection{Description of the WASP7}

The development of the WASP started in 1970s, supported by the U.S. EPA. The

WASP7 is the latest version of the WASP, and links hydrodynamic and sediment transport models that be used to solve problems such as eutrophication or heavy metal pollution. To establish our model for analysis by the WASP7, the waterbody of the river was divided into 12 superficial segments of equal size in each city/district; this twodimensional (2-D) horizontal distribution was established to take account of aquaculture (Fig. 1). Due to a scarcity of data on actual river depth, it was reasonably assumed that the $\mathrm{Wu}$ River is a shallow river, containing $0.1 \mathrm{~m}$ (sediment) and $0.047 \mathrm{~m}$ (soil cultivated for rice) in its vertical section. These measurements are consistent with those found in many studies of samples of surface sediments $(<10 \mathrm{~cm}$ in depth) from contaminated sites (Fang et al. 2019). Table 1 presents the model's core elements; a step-size time variable of 1 year is used for each interaction.

As mentioned before, total chromium concentrations in water have been restricted by the Taiwanese EPA. Water quality of total chromium were acquired from the regular monitoring stations in the Wu River. The Taiwanese EPA regularly conducts manual water quality sampling every month to compare data from regular monitoring stations.

164 The $\mathrm{Cr}(\mathrm{VI})$ concentration was assumed to account for $7.2 \%$ of the total chromium 165 concentration in water based on the assumption that $\leq 7.2 \%$ of the total chromium in water is in the hexavalent (Cr(VI)) form (Proctor et al. 2002). In addition, the $\mathrm{Cr}(\mathrm{VI})$

167 concentration was assumed to account for $1 \%$ of the total chromium concentration in 168 soil (Hsu et al., 2012). The effects of chemical reactions with particulate materials in 169 water were excluded from this study. 


\subsection{Verification of the WASP7}

173 and calibration, and is also used in this study. It can be calculated as the average absolute 174 percentage error for each time period minus actual values, divided by actual values as 175 follows, where $A_{t}$ is the actual value and $F_{t}$ is the forecast value:

$176 \quad M A P E=\frac{1}{n} \sum_{t=1}^{n}\left|\frac{A_{t}-F_{t}}{A_{t}}\right|$

\subsection{Calculation of ingestion exposure dose}

We used Eq. (2) to calculate the cancer risk from $\mathrm{Cr}(\mathrm{VI})$ contamination:

$180 \quad$ Risk $=\frac{C \times I R \times E D}{B W} \times \mathrm{CSF}$

181 where the lifetime average daily dose (LADD) value (in $\mathrm{mg} / \mathrm{kg} /$ day) was used in this 182 study to calculate exposure from ingestion. $\mathrm{C}$ is the ingested $\mathrm{Cr}(\mathrm{VI})$ concentration $183(\mathrm{mg} / \mathrm{kg}), \mathrm{I}$ is the intake volume $(\mathrm{kg} /$ day) of rice of the Taiwanese population, $E D$ is 184 the exposure duration with regard to the age range of population, and BW is the average 185 body weight in Taiwan $(\mathrm{kg})$. Table S1 tabulates the body weights of Taiwanese males 186 and females, and their intake volume of different plants at various ages. CSF is the 187 cancer slope factor (0.5/mg/kg/day) (U.S. EPA 2010).

188 Therefore, an estimation of the death toll from gastric cancer ( $G_{\text {cancer }}$, per capita) for 189 this study was formulated as follows (Eq. (3)):

$190 G_{\text {cancer }}=$ Risk $\times \mathrm{F} \times \mathrm{P}$

191 Where $\mathrm{P}$ is total exposure population (capita) and $\mathrm{F}$ is the mortality rate of gastric cancer 192 in Taichung city is $51.16 \%$, and the mortality rate of gastric cancer in Changhua county 193 is $48.31 \%$ (Tsuang 2016 ). 


\subsection{Calculation of value of loss of life}

The value of statistical life year (VSLY) method was applied to recognize that any

197 change in an individual's mortality risk. The VSLY method uses attributable risk (AR),

198 which is the ratio of the estimated excess population who died of gastric cancer (per capita) as a result of $\mathrm{Cr}(\mathrm{VI})$ exposure and the actual population $(\mathrm{P})$ who died of gastric cancer without $\mathrm{Cr}(\mathrm{VI})$ exposure (per capita). The AR value was then applied to an established life table to calculate the LLE in the study area. The estimated years of economic loss after estimation of the AR of $\mathrm{Cr}(\mathrm{VI})$ pollutants; it can be calculated as

203 follows (Eq. (5)):

204 Value of loss life $=\frac{L L E \times P \times V S L Y}{Y}$

205 where is $\mathrm{Y}$ is the life expectancy (y). Detailed calculations can be referred to our 206 previous research (Tseng et al. 2018 \& 2019).

\subsection{Calculation of pollution prevention cost}

The costs of wastewater treatment were considered to include construction and operation and maintenance (O\&M) costs. These were calculated using Eq. (5):

$$
C_{w w}=C_{\text {construct }}+C_{O \& M}
$$

212 The construction costs for chemical oxidation treatment and ion-exchange treatment in

213 Taiwan were roughly US\$350,000 and US\$83,000, and these treatments can last for 25

214 and 5 years, respectively (Industrial Development Bureau 2004). The O\&M costs 215 evaluated in this study comprised electricity costs, medical costs, general maintenance 216 costs, and personnel expenses.

\section{Results and discussion}




\section{1. $\operatorname{Cr}(V I)$ accumulation in soil}

Figure 2 shows the $\mathrm{Cr}(\mathrm{VI})$ accumulation in cultivated soils in the four city/districts.

The soil in Wufen district was heavily polluted, containing 16,799 $\mu \mathrm{g} / \mathrm{kg} \mathrm{Cr}(\mathrm{VI})$, followed by Changhua city $(4,273 \mu \mathrm{g} / \mathrm{kg})$, Homei district $(3,977 \mu \mathrm{g} / \mathrm{kg})$, and Dali district $(3,271 \mu \mathrm{g} / \mathrm{kg})$. The $\mathrm{Cr}(\mathrm{VI})$ accumulation is soils were higher than original expects and results of other counties with similar conditions. In India, it was found that $79.5 \mu \mathrm{g} / \mathrm{kg}$ and $45.8 \mu \mathrm{g} / \mathrm{kg} \mathrm{Cr}(\mathrm{VI})$ was accumulated in cultivated rice and corn (Mishra et al., 1995 \& 1997), while oats and lettuce plants respectively accumulated 941.1 $\mu \mathrm{g} / \mathrm{kg}$ and $63.9 \mu \mathrm{g} / \mathrm{kg} \mathrm{Cr}$ (VI) (Asfaw et al 2017; Wyszkowski and Radziemska 2013). A case study of Taiwan indicated that partition coefficients of heavy metal species and particulate settling rates play an important role in the distribution of dissolved heavy metals (Liu et al. 2012).

The accumulation rates were also different over the course of a year. $\operatorname{The} \mathrm{Cr}(\mathrm{VI})$ contamination was highest on day 72 in Wufen district, on day 234 in Dali district, on day 310 in Homei district, and on day 325 in Changhua city. A previous study showed that the residence time of chromium in water ranges from 4.6 to 18 years (Schmidt and Andren 1984). Cr(VI) accumulation may be affected by the distribution distances, and the area and type of cultivation of the land under study. It was found in this study that the anthropogenic $\mathrm{Cr}(\mathrm{VI})$ was mainly discharged from factories located in Taichung city, and thus higher concentrations of $\mathrm{Cr}(\mathrm{VI})$ accumulated in the cultivated soils of Taichung city than in those of Changhua city. Impressively, smaller cultivated areas accumulated maximum concentrations of $\mathrm{Cr}(\mathrm{VI})$ in short time. $\mathrm{Cr}(\mathrm{VI})$ transmission throughout the environment involves multicomponent linked actions and critical processes specific to the sediment-water system.

Figure 2 here. 


\subsection{Verification of the WASP7 model}

The results of the verification of the WASP7 model are shown in Table 2. The MAPE results were $28.5 \%$ and $28.8 \%$ in Taichung city and Changhua county, respectively. According to the statistical data from Taiwan EPA (2019), the monitored $\mathrm{Cr}(\mathrm{VI})$ concentrations in cultivated soil were $1.7-2.5 \mathrm{mg} / \mathrm{kg}$ in Taichung city and 2.9$3.5 \mathrm{mg} / \mathrm{kg}$ in Changhua county. The simulated results of the WASP7 model were consistent with these results. In particular, the high concentrations of $\mathrm{Cr}(\mathrm{VI})$ contamination in the soil can be attributed to the high density of electroplating factories in Wu river watershed (Chiang et al. 2010). When $\mathrm{Cr}(\mathrm{VI})$ accumulates in cultivated soil, 254 it is absorbed by food crops and thus ultimately ingested by humans via the food chain. $\mathrm{Cr}(\mathrm{VI})$ accumulation in soil was the greatest in Changhua city $(4.3 \mathrm{mg} / \mathrm{kg})$, followed by Homei district (4.0 mg/kg), Dali district (3.3 mg/kg), and Wufen district (2.2 mg/kg). An acceptable soil chromium concentration of $64 \mathrm{mg} / \mathrm{kg}$ was established to protect environmental and human health (CCME 2015). These findings suggest that rice plants irrigated with downstream river water carry a greater carcinogenic risk.

\subsection{Health costs associated with $\mathrm{Cr}(\mathrm{VI})$ contamination}

The risk of gastric cancer caused by $\mathrm{Cr}(\mathrm{VI})$ contamination was an average of $2643 \times 10^{-7}-15.2 \times 10^{-6}$ in Taichung city and $1.3 \times 10^{-6}-76.3 \times 10^{-6}$ in

265 Changhua county (Table 3). Specifically, eating vegetables was associated with the 266 greatest risks of causing gastric cancer, followed by eating corn and rice. More seriously, 267 young children had a threefold greater risk than adults. This is due to the relative intake rate being higher for young children, as a result of their lower body weight. Therefore, 
the LADD values were higher for young children. Female children and adults had higher cancer risks than their male counterparts, due to females' lower body weights. The AR values were $2.2 \times 10^{-5}-1.3 \times 10^{-3}$ in Taichung city and $7.8 \times$ $10^{-5}-4.5 \times 10^{-3}$ in Changhua county. The exposure population in Taichung city and Changhua county was 278 million and 128 million in 2017 . Therefore, the estimated values for the population who died of gastric cancer are 1 for rice, 3-6 for corn, and 22-47 for vegetables each year.

The LLE due to Cr(VI) pollution was $0.002-0.103$ years in Taichung city and 0.006-0.361 years in Changhua county. That is, the average life expectancy in Taichung city decreased from 80.3 to 80.2 years, whereas the average life expectancy in Changhua county decreased from 79.9 to 79.5 years. The VSLYs in Taichung city were US\$6.2 million for rice, US\$42 million for corn, and US\$360 million for vegetables each year, respectively (Fig. 3). In addition, the VSLYs in Changhua county were US\$10 million for rice, US\$68 million for corn, and US\$587 million for vegetables each year. The VSLY was an average of 1.5 times higher in Changhua county than in Taichung city. Although most $\mathrm{Cr}(\mathrm{VI})$ was discharged from Taichung city, the increased health risks and losses occurred downstream in Changhua county.

\subsection{Cost of pollution prevention}

In this study the costs of the two most common applied treatments to control $\mathrm{Cr}(\mathrm{VI})$ contamination were evaluated, namely chemical oxidation and ion-exchange treatments. The key advantages of ion exchange are that it enables recovery of valuable metals, its selectivity and that it produces low volumes of sludge (Jachuła and Hubicki 2013). On average, $706,210 \mathrm{~m}^{3}$ of sludge containing $0.1 \mathrm{mg} / \mathrm{kg} \mathrm{Cr}(\mathrm{VI})$ contamination is discharged from factories into the Wu River each year (Taiwan EPA 2019) and, as 
shown in Fig. 4, the chemical oxidation and ion-exchange treatments to remove $\mathrm{Cr}(\mathrm{VI})$ contamination from the river cost US\$71,800 and US\$65,367, annually. The medical cost for the ion-exchange treatment was 10 times greater than that for chemical

297 oxidation treatment (US\$1,320/y vs. US\$112/y). However, the O\&M cost of the chemical oxidation treatment was US\$10,500/y, greater than that for ion-exchange treatment (US\$2,500/y). When divided by their respective life expectancies, the construction costs of both treatments were similar (US\$14,000-16,667).

These results show that it is critical for the government to use either of these treatments to reduce $\mathrm{Cr}(\mathrm{VI})$ pollution in the $\mathrm{Wu}$ River and thus reduce health costs, given that the VSLY caused by the health risks of crops irrigated with Wu River water was US\$16.3 million/y for rice, US\$110.5 million/y for corn, and US\$947.3 million/y for other vegetables. It is recommended that the factories near the Taichung and Fuma channels reduce their discharge of $\mathrm{Cr}(\mathrm{VI})$, as this at-source action would be more effective than end-pipe treatment.

\section{Conclusions}

In this study a WASP7 model was used to explore the transmission of $\mathrm{Cr}(\mathrm{VI})$ contamination in a water-sediment system and its flux into cultivated soils in the $\mathrm{Wu}$ River watershed. The Wu River watershed enters the area in Taichung city (upstream) and flows into irrigation channels in Changhua county (downstream). The soil in Wufen district was found to be heavily polluted, containing $16,799 \mu \mathrm{g} / \mathrm{kg} \operatorname{Cr}(\mathrm{VI})$, followed by Changhua city $(4,273 \mu \mathrm{g} / \mathrm{kg})$, Homei district $(3,977 \mu \mathrm{g} / \mathrm{kg})$, and Dali district $(3,271$ $\mu \mathrm{g} / \mathrm{kg}) . \mathrm{Cr}(\mathrm{VI})$ accumulation may be affected by distribution distances, cultivated areas, and types of cultivations. The MAPE results were $28.5 \%$ and $28.8 \%$ in Taichung city and Changhua county, consistent with the simulated results from the WASP7 model. 
The risk of gastric cancer caused by $\mathrm{Cr}(\mathrm{VI})$ contamination was an average of $3 \times 10^{-7}-15.2 \times 10^{-6}$ in Taichung city and $1.3 \times 10^{-6}-76.3 \times 10^{-6}$ in

321 Changhua county. The VSLYs were US\$6.2-10 million for rice, US\$42-60 million for corn, and US\$360-580 million for vegetables each year, respectively. The VSLY were on average 1.5 times higher in Changhua county than in Taichung city. $\mathrm{Cr}(\mathrm{VI})$ contamination from the Wu river would annually cost an average of US\$71,800 and US\$65,367, respectively. It is therefore critical that the government uses these or other treatments to reduce $\mathrm{Cr}(\mathrm{VI})$ contamination in the Wu River, and thus reduce gastric cancer-associated health costs. Importantly, the use of these at-source reduction techniques will be more efficient that those that remove $\mathrm{Cr}(\mathrm{VI})$ once it has been released into the river.

\section{Acknowledgments}

The authors thank the Ministry of Science and Technology of the Republic of China for financial support. They also acknowledge the Taiwan EPA and Water

335 Resources Agency, the Ministry of Economic Affairs, the Ministry of Health and 336 Welfare, and other governmental agencies for assistance with data collection. The 337 authors further thank the anonymous reviewers for their invaluable comments and 338 suggestions.

\section{Declarations}

341 - Conflicts of interest/Competing interests: The authors declare that they have no conflict of interest. 
344 (institutional, general or subject specific) repository that issues datasets with DOIs $345 \quad$ (non-mandated deposition)

346 - Funding: n/a.

347 - Authors' contributions: Conceptualization: Chao-Heng Tseng; Methodology: 348 Chao-Heng Tseng; Formal analysis and investigation: Yun-Ting Chen; Writing 349 original draft preparation: Ying-Chu Chen; Funding acquisition: Chao-Heng Tseng; 350 Resources: Chao-Heng Tseng, Ying-Chu Chen; Supervision: Chao-Heng Tseng, $351 \quad$ Ying-Chu Chen

353 References

354 Akinremi OO, Janzen RL, Lemke RL, Larney FJ (2000) Response of canola, wheat and 355 green beans to leonardite additions. Can J Soil Sci 80:437-443.

356 Allison JD, Allison TL (2005) Partition Coefficients for Metals in Surface Water, Soil, 357 and Waste. US EPA, Washington, DC.

358 Asfaw TB, Tadesse TM, Ewnetie AM (2017) Determination of total chromium and 359 chromium species in Kombolcha tannery wastewater, surrounding soil, and lettuce 360 plant samples, South Wollo, Ethiopia. Advance Chem:6191050.

361 Canadian Council of Ministers of the Environment (CCME) (2015) Canadian Soil 362 Quality Guidelines for the Protection of Environmental and Human Health. 363 Scientific criteria document. 364 http://www.ccme.ca/en/resources/canadian_environmental_quality_guidelines/in $365 \quad$ dex.html Accessed 14 Feb 2020

366 Chang FH, Wang SL, Huang YL, Tsai MH, Yu ST, Chang LW (2006a) Biomonitoring 367 of chromium for residents of areas with a high density of electroplating factories. $368 \quad J$ Expo Sci Environ Epidemiol 16:138-146. 
Chang FH, Wang HJ, Wang SL, Wang YC, Hsieh DPH, Chang LW, Ko YC (2006b) Survey of urinary nickel in residents of areas with a high density of electroplating factories. Chemosphere 65(10):1723-1730.

Chiang CT, Hwang YH, Su CC, Tsai KY, Lian leB, Yuan TH, Chang TK (2010) Elucidating the underlying causes of oral cancer through spatial clustering in highrisk areas of Taiwan with a distinct gender ratio of incidence. Geospat Health $4: 230-242$.

Cho E, Arhonditsis GB, Khim J, Chung S (2016) Modeling metal-sediment interaction processes: Parameter sensitivity assessment and uncertainty analysis. Environ Model Soft 80:159-174.

Chow YN, Lee LK, Zakaria NA, Foo KY (2018) Phototoxic effects of trivalent chromium-enriched water irrigation in Vigna unguiculata seeding. J Clean Prod, article in press. doi: 10.1016/j.jclepro.2018.07.144

Costa M (2003) Potential hazards of hexavalent chromate in our drinking water. Toxicol Appl Pharmacol 188:1-5.

Council of Agriculture (2015) Agricultural Irrigation White book. Council of Agriculture, Taipei.

Department of Irrigation and Engineering (2018) Irrigation Drainage Summary. Department of Irrigation and Engineering, Taipei.

Ding D, Zhu Y, Jang C, Lin CJ, Wang S, Fu J, Gao J, Deng S, Xie J, Qiu X (2016) Evaluation of health benefit using BenMAP-CE with an integrated scheme of model and monitor data during Guangzhou Asian Games. J Environ Sci 42:9-18.

Fang X, Peng B, Wang X, Song Z, Zhou D, Wang Q, Qin Z, Tan C (2019) Distribution, contamination and source identification of heavy metals in bed sediments from the lower reaches of the Xiangjiang River in Human province, China. Sci Total 
Forstner U, Muller G (1973) Heavy metal accumulation in river sediments: A response to environmental pollution. Geoforum 14:53-61.

397

Ghrefat H, Yusuf N (2006) Assessing $\mathrm{Mn}, \mathrm{Fe}, \mathrm{Cu}, \mathrm{Zn}$, and $\mathrm{Cd}$ pollution in bottom sediments of Wadi Al-Arab Dam, Jordan. Chemosphere 65:2114-2121.

Gustafson JP, Persson I, Oromieh AG, Van Schaik JWJ, Sjöstedt C, Kleja DB (2014) Chromium(III) complexation to natural organic matter: Mechanisms and modeling. Environ Sci Technol 48:1753-1761.

Haney Jr. JT, Erraguntla N, Sielken Jr. RL, Valdez-Flores C (2014) Development of an inhalation unit risk factor for hexavalent chromium. Regul Toxicol Pharmacol 68:201-211.

IARC (1999) Chromium, Nickel and Welding, IARC Monographs on the Evaluation of Carcinogenic Risks to Humans 49. IARC, Lyon.

Industrial Development Bureau (2004) Environmental Technical Assistance Project. Industrial Development Bureau, Taipei.

Jachuła J, Hubicki Z (2013) Removal of Cr(VI) and As(V) ions from aqueous solutions by polyacrylate and polystyrene anion exchange resins. Appl Water Sci 3:653-664.

Jiann KT, Wen LS (2009) Intra-annual variability of distribution patterns and fluxes of dissolved trace metals in a subtropical estuary. J Mar Syst 75:87-99.

Jobby R, Jha P, Yadav AK, Desai N (2007) Biosorption and biotransformation of hexavalent chromium [Cr(VI)]: A comprehensive review. Chemosphere 207:255266.

Kotaś J, Stasicka Z (2000) Chromium occurrence in the environment and methods of its speciation. Environ Pollut 107:263-283.

Keesstra SD, Bouma J, Wallinga J, Tittonell P, Smith P, Cerdá A, Montanarella L, 

Jansen B, Fresco LO (2016) The significance of soils and soil science towards realization of the United Nations Sustainable Development Goals. Soil 2:111-128.

Key G, Whitfield MG, Cooper J, De Vries FT, Collison M, Dedousis T, Heathcote R, Roth B, Mohammed S, Molyneux A, Van der Putten WH, Dicks LV, Sutherland WJ, Bardgett RD (2016) Knowledge needs, available practices, and future

Kotaś J, Stasicka Z (2000) Chromium occurrence in the environment and methods of

Knightes CD, Ambrose Jr RB, Avant B, Han Y, Acrey B, Bouchard DC, Zepp R, Wool $\mathrm{T}$ (2019) Modeling framework for simulating concentrations of solute chemicals, T nanoparticles, and solids in surface waters and sediments: WASP8. Advanced Toxicant Module. Environ Model Soft 111:444-458.

Lei J (2016) Assessment of the health costs of hexavalent chromium from industrial wastewater in central Taiwan. Master's thesis, National Taipei University of Technology, Taipei. https://ndltd.ncl.edu.tw/cgibin/gs32/gsweb.cgi/login?o $=$ dnclcdr\&s $=\mathrm{id}=\% 22104 \mathrm{TIT} 05087020 \% 22 . \&$ search $\underline{\text { mode }=\text { basic }}$. Accessed 24 March 2020

Linos A, Petralias A, Christophi CA, Christoforidou E, Kouroutou P, Stoltidis M, Veloudaki A, Tzala E, Makris KC, Karagas MR (2011) Oral ingestion of hexavalent chromium through drinking water and cancer mortality in an industrial area of Greece-An ecological study. Environ Health 10:50.

Liu J, Zhang XH, Tran H, Wang DQ, Zhu YN (2011) Heavy metal contamination and risk assessment in water, paddy soil, and rice around an electroplating plant. Environ Sci Pollut Res 18:1623-1632. 
Liu M, Chen J, Sun X, Hu Z, Fan D (2019) Accumulation and transformation of heavy metals in surface sediments from the Yangtze River estuary to the East China Sea shelf. Environ Pollut 245:111-121.

Liu W, Chen W, Chang Y (2012) Modeling the transport and distribution of lead in tidal Keelung river estuary. Environ Earth Sci 65:39-47.

Miranda AI, Ferreira J, Silveira C, Relvas H, Duque L, Robeling P, Lopes M, Costa S, Monteiro A, Gama C, Sá E, Borrego C, Teixeira JP (2016) A cost-efficiency and health benefit approach to improve urban air quality. Sci Total Environ 569570:342-351.

Mishra S, Shanker K, Srivastava MM, Srivastava S, Shrivastav R, Dass S, Prakash S, (1997) A study on the uptake of trivalent and hexavalent chromium by paddy (Oryza sativa): Possible chemical modifications in rhizosphere. Agricul Ecosys Environ 62:53-58.

Mishra S, Singh V, Srivastava S, Srivastava R, Srivastava MM, Dass S, Satsangi GP, Prakash S (1995) Studies on uptake of trivalent and hexavalent chromium by maize (Zea mays). Food Chem Toxicol 33:393-397.

Mohanty K, Jha M, Meikap BC, Biswas MN (2005) Removal of chromium(VI) from dilute aqueous solutions by activated carbon developed from Terminalia arjuna nuts activated with zinc chloride. Chem Eng Sci 60:3049-3059.

Pandey MD, Nathwani J (2003) Canada Wide Standard for particulate matter and ozone: cost-benefit analysis using a Life Quality Index. Risk Analysis 23:55-67.

Pradhan D, Sukla LB, Sawyer M, Rahman PKSM (2017) Recent bioreduction of hexavalent chromium in wastewater treatment: A review. J Ind Eng Chem 55:1-20.

Proctor DM, Otani JM, Finley BL, Paustenbach DJ, Bland JA, Speizer N, Sargent EV (2002) Is hexavalent chromium carcinogenic via ingestion? A weight-of-evidence 
review. J Toxicol Environ Health A 65:701-746.

Raptis S, Gasparatos D, Economou-Eliopoulos M, Petridis A (2018) Chromium uptake by lettuce as affected by the application of organic matter and $\mathrm{Cr}(\mathrm{VI})$-irrigation water: Implications to the land use and water management. Chemosphere 210:597606.

Shih YH, Tseng CH (2015) Co-benefits of mercury reduction in Taiwan: A case study of clean energy development. Sustain Sci 10:61-73.

Sundaray, S.K., Nayak, B.B., Lin, S., Bhatta, D., 2011. Geochemical speciation and risk assessment of heavy metals in the river estuarine sediments-A case study: Mahanadi basin, India. J. Hazard Mater. 186, 1837-1846.

Taichung Irrigation Association, 2009. Taichung Cultivation Magazine. Taichung Irrigation Association, Taipei.

Taiwan EPA, 2008. Heavy Metal Inspection Planning for Irrigation Water Monitoring Network System. Taiwan EPA, Taipei.

Taiwan EPA, 2019. Environmental Data. Taiwan EPA, Taipei.

Taiwan Food and Drug Administration, 2018. National Food Consumption Database, Taiwan Food and Drug Administration, Taipei. Available at: http://tnfcds.cmu.edu.tw/index.php?action=index (Accessed 15 Feb 2019)

Tseng, C.H., Lei, C., Chen, Y.C., 2018. Evaluating the health costs of oral hexavalent chromium exposure from water pollution: A case study in Taiwan. J. Clean. Prod. $172,819-826$.

Tsuang, B., 2016. Taiwan Cancer Maps. Taiwancancermap.csmu-liawyp.tw. Available at: http://taiwancancermap.csmu-liawyp.tw/. (Accessed 25 Apr 2018)

Unceta, N., Séby, F., Malherbe, J., Donard, O.F.X., 2010. Chromium speciation in solid matrices and regulation: A review. Anal. Bioanal. Chem. 397, 1097-1111. 
U.S. Environmental Protection Agency (EPA), 2003. National primary drinking water regulations 40CFR14162. U.S. EPA, Washington, DC. Available at: http://edocket.access.gpo.gov/cfr_2003/julqtr/40cfr141.62.htm. (Accessed $15 \mathrm{Feb}$ 2019)

U.S. Environmental Protection Agency (EPA), 2011. The Benefits and Costs of the Clean Air Act from 1990 to 2020. U.S. EPA, Washington, DC. Available at: https://www.epa.gov/sites/production/files/201507/documents/summaryreport.pdf. (Accessed 15 Feb 2019)

U.S. Environmental Protection Agency (EPA), 2010. Toxicological Review of Hexavalent Chromium. U.S. EPA (CAS No. 1840-29-9), Washington, DC.

Water Resources Agency, 2011. Dadu Wair Project. Water Resources Agency, Taipei.

Wyszkowski, M., Radziemska, M., 2013. Assessment of tri- and hexavalent chromium phytotoxicity on oats (Avena sativa L.) biomass and content of nitrogen compounds. Water Air Soil Pollut. 224, 1619.

Xu, X., Yekeen, T.A., Liu, J., Zhuang, B., Li, W., Huo, X., 2015. Chromium exposure among children from an electronic waste recycling town of China. Environ. Sci. Pollut. Res. Int. 22, 1778-1785.

Yuan, T.H., Lian, leB., Tsai, K.Y., Chang, T.K., Chiang, C.T., Su, C.C., Hwang, Y.H., 2011. Possible association between nickel and chromium and oral cancer: A casecontrol study in central Taiwan. Sci. Total. Environ. 409, 1046-1052.

Zhang, J., Li, S., 1997. Cancer mortality in a Chinese population exposed to hexavalent chromium in water. J. Occup. Environ. Med. 39, 315-319. 


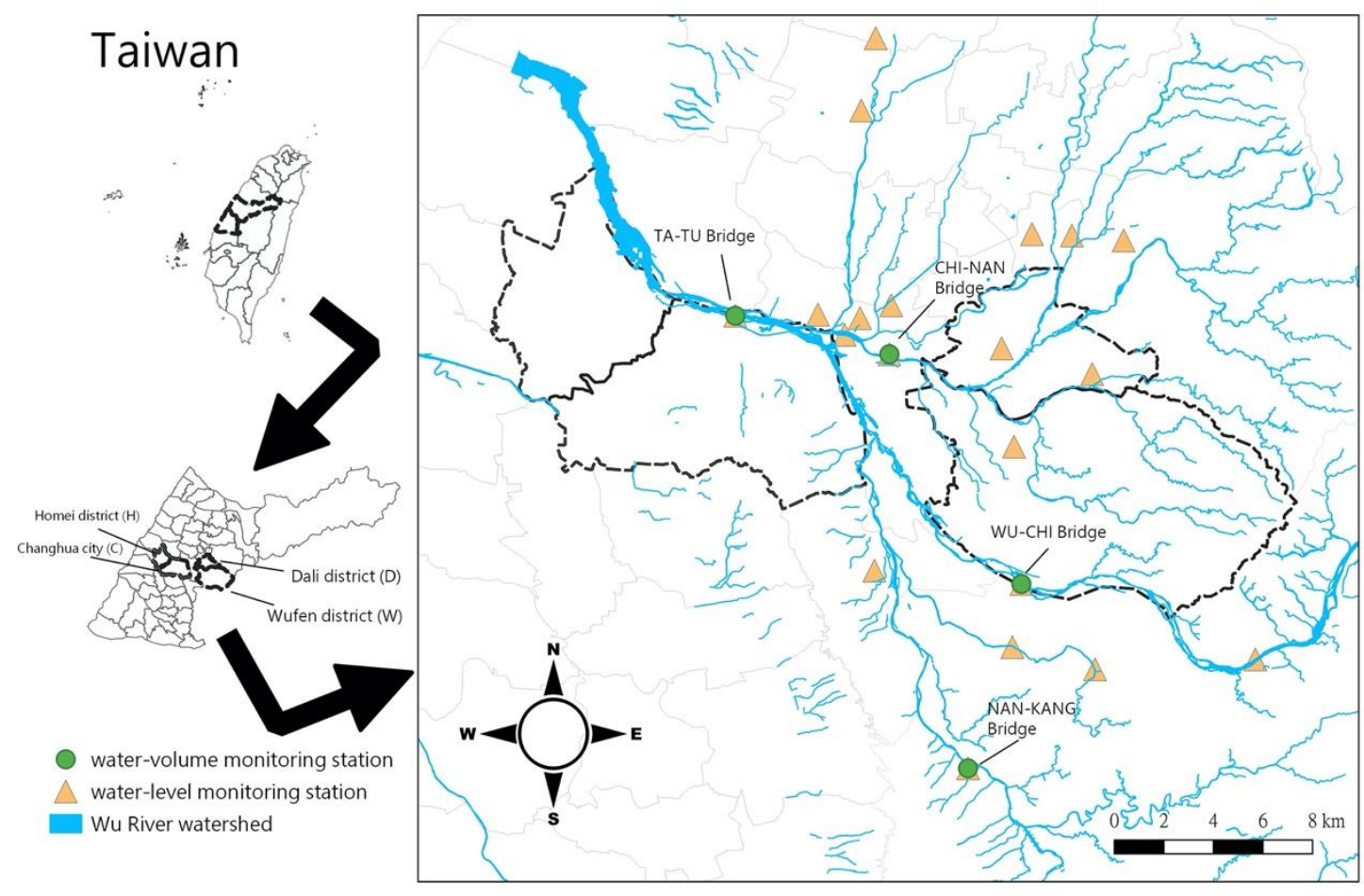

518

519 Fig. 1. Locations of Changhua county, Taichung city, and the Wu River watershed. 


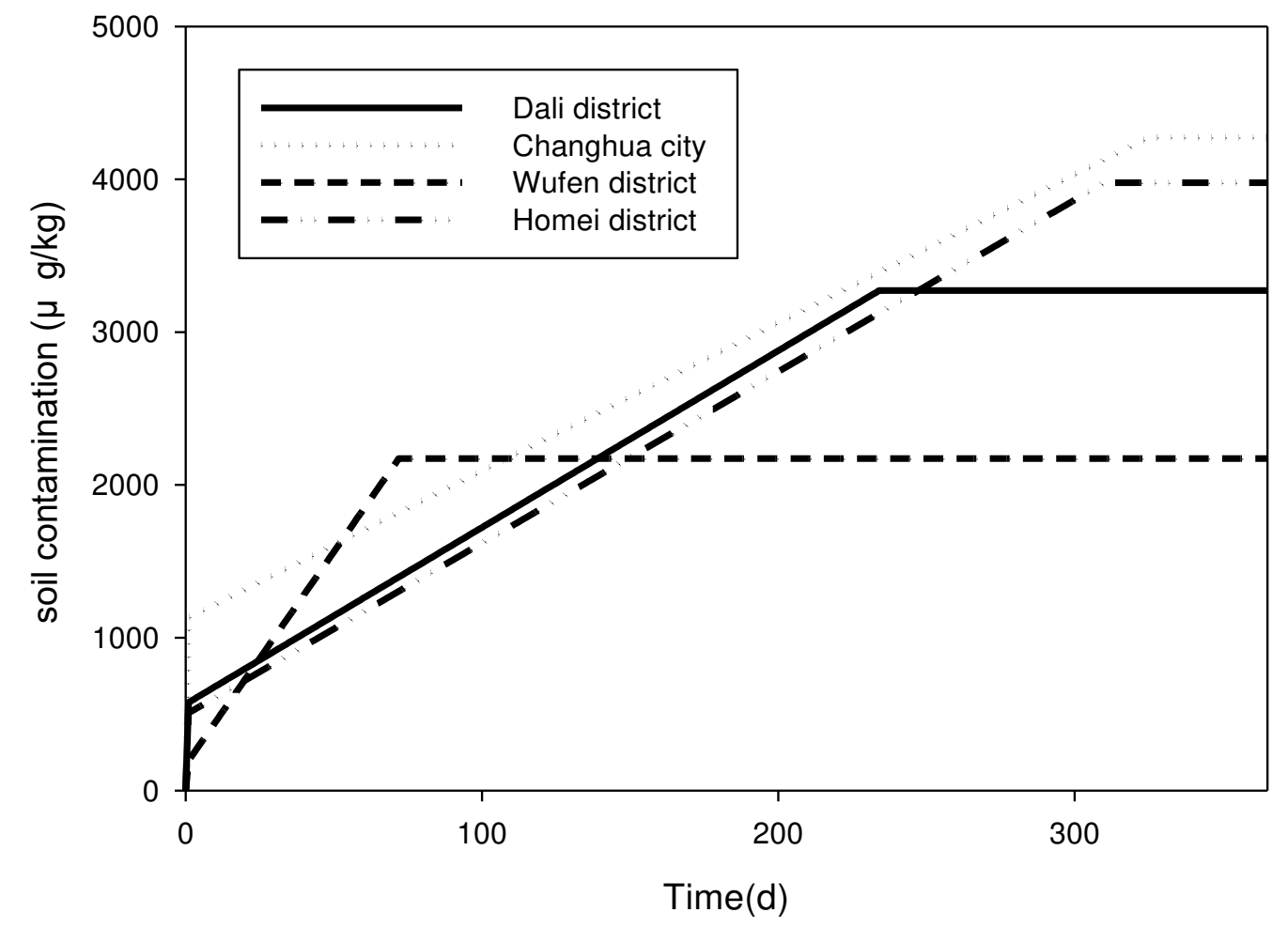

524 Fig. $2 \mathrm{Cr}(\mathrm{VI})$ contamination in different cities/districts simulated by the WASP model 


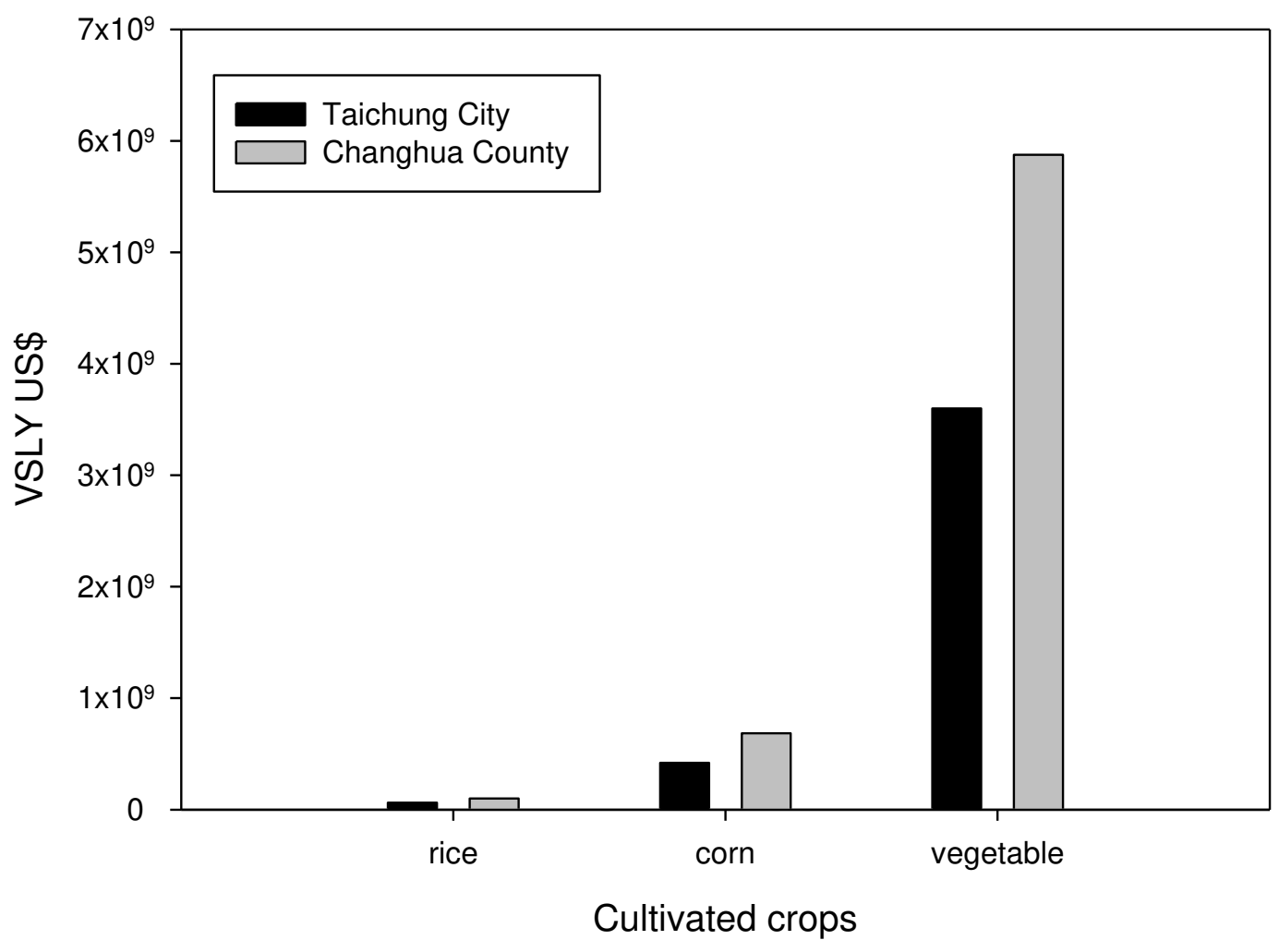

530 Fig. 3. The VSLY results from different cultivated crops in the Taichung city and 


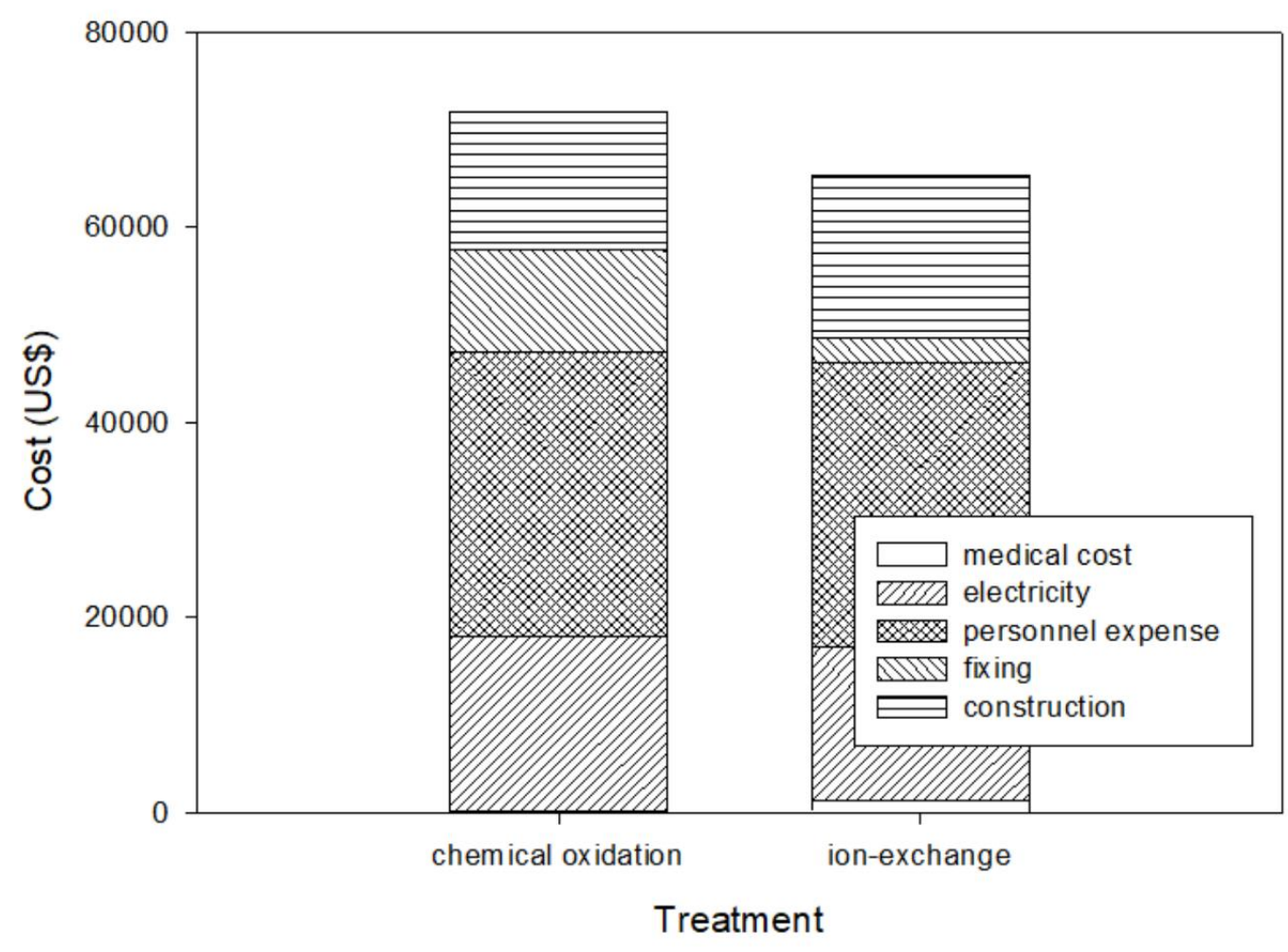

535 Fig. 4. The pollution-prevention costs for chemical oxidation and ion-exchange treatment in the Wu River. 
Table 1. Kinetic constants for the WASP7 model in this study.

\begin{tabular}{|c|c|c|c|c|c|c|}
\hline \multirow{2}{*}{ Parameter } & \multirow{2}{*}{ Unit } & \multicolumn{4}{|c|}{ City/district } & \multirow{2}{*}{ Source } \\
\hline & & $\mathbf{H}$ & $\mathbf{C}$ & D & $\mathbf{W}$ & \\
\hline $\begin{array}{l}\text { Segment } \\
\text { length }\end{array}$ & $\mathrm{m}$ & 1,348 & 1,452 & 1,211 & 34.96 & \multirow{2}{*}{$\begin{array}{l}\text { Taichung Irrigation } \\
\text { Association, } 2008\end{array}$} \\
\hline $\begin{array}{l}\text { Segment } \\
\text { width }\end{array}$ & $\mathrm{m}$ & 4,045 & 4,357 & 3,635 & 104.88 & \\
\hline River depth & $\mathrm{m}$ & \multicolumn{4}{|c|}{0.047} & $\begin{array}{c}\text { Council of } \\
\text { Agriculture, } 2015\end{array}$ \\
\hline Soil depth & $\mathrm{m}$ & \multicolumn{4}{|c|}{0.1} & Tseng et al., 2018 \\
\hline $\begin{array}{c}\text { Soil } \\
\text { infiltration } \\
\text { coefficient }\end{array}$ & $\mathrm{cm} / \mathrm{s}$ & \multicolumn{4}{|c|}{$2 \times 10^{-5}$} & $\begin{array}{c}\text { Department of } \\
\text { Irrigation and } \\
\text { Engineering, } 2018\end{array}$ \\
\hline $\begin{array}{l}\text { Water flow } \\
\text { rate }\end{array}$ & $\mathrm{m}^{3} / \mathrm{s}$ & 3.498 & 4.058 & 1.99 & 0.0016 & $\begin{array}{l}\text { Taichung Irrigation } \\
\text { Association, } 2008\end{array}$ \\
\hline $\begin{array}{c}\mathrm{Cr}(\mathrm{VI}) \\
\text { concentration } \\
\text { in water }\end{array}$ & $\mu g / L$ & 48 & 56 & 18 & 14 & Taiwan EPA, 2008 \\
\hline Settling rate & $\mathrm{m} / \mathrm{d}$ & \multicolumn{4}{|c|}{6.56} & $\begin{array}{c}\text { Water Resources } \\
\text { Agency, } 2011\end{array}$ \\
\hline $\begin{array}{l}\text { Partition } \\
\text { coefficients }\end{array}$ & $\begin{array}{c}\log \\
\mathrm{KD} \text { in } \\
\mathrm{L} / \mathrm{kg}\end{array}$ & \multicolumn{4}{|c|}{1.1} & $\begin{array}{l}\text { Allison and Allison, } \\
2005\end{array}$ \\
\hline $\begin{array}{l}\text { Suspended } \\
\text { solids in } \\
\text { water }\end{array}$ & $\mathrm{mg} / \mathrm{L}$ & 20 & 11.8 & 18 & 6.1 & $\begin{array}{l}\text { Taichung Irrigation } \\
\text { Association, } 2008\end{array}$ \\
\hline
\end{tabular}


Table 2 Results of MAPE for the WASP7 model in this study.

\begin{tabular}{|c|c|c|c|c|}
\hline City/district & D & W & H & C \\
\hline Total Cr concentration in water $(\mathrm{mg} / \mathrm{L})^{\mathrm{a}}$ & 0.25 & 0.2 & 0.67 & 0.76 \\
\hline Cr(VI) concentration $(\mathrm{mg} / \mathrm{L})^{\mathrm{b}}$ & 0.018 & 0.014 & 0.048 & 0.054 \\
\hline Average Cr(VI) concentration $(\mathrm{mg} / \mathrm{L})$ & \multicolumn{2}{|c|}{0.016} & \multicolumn{2}{|c|}{0.051} \\
\hline Monitored Cr(VI) concentration in soil $(\mathrm{mg} / \mathrm{kg})$ & 2.5 & 1.71 & 2.93 & 3.50 \\
\hline Simulated Cr(VI) concentration $(\mathrm{mg} / \mathrm{kg})$ & 3.27 & 2.18 & $3 / 97$ & 4.27 \\
\hline Average simulated Cr(VI) concentration $(\mathrm{mg} / \mathrm{kg})$ & \multicolumn{2}{|c|}{2.73} & \multicolumn{2}{|c|}{4.12} \\
\hline MAPE $(\%)$ & \multicolumn{2}{|c|}{28.5} & \multicolumn{2}{|c|}{28.8} \\
\hline
\end{tabular}

${ }^{a}$ The $\operatorname{Cr}(\mathrm{VI})$ concentration was assumed to account for $7.2 \%$ of the total chromium concentration in water. ${ }^{b}$ the $\mathrm{Cr}(\mathrm{VI})$ concentration was assumed to account for $1 \%$ of the total chromium concentration in soil. 
Table 3 Health risks from intake of different cultivated plants for different ages of sexes in the Taichung city and Changhua county.

\begin{tabular}{|c|c|c|c|c|c|c|c|}
\hline \multirow{2}{*}{\multicolumn{2}{|c|}{$\begin{array}{l}\text { Cultivation } \\
\text { Age (y) Sex }\end{array}$}} & \multicolumn{2}{|c|}{ Rice } & \multicolumn{2}{|c|}{ Corn } & \multicolumn{2}{|c|}{ Vegetable } \\
\hline & & Taichung & Changhua & Taichung & Changhua & Taichung & Changhua \\
\hline \multirow{2}{*}{$1-6$} & $\mathrm{M}$ & 0.4 & 2.1 & 2.9 & 14.6 & 24.7 & 124.4 \\
\hline & $\mathrm{F}$ & 0.4 & 2.2 & 3.0 & 14.9 & 25.3 & 127.5 \\
\hline \multirow{2}{*}{$7-12$} & $\mathrm{M}$ & 0.3 & 1.5 & 2.0 & 10.3 & 17.5 & 88.0 \\
\hline & $\mathrm{F}$ & 0.3 & 1.5 & 2.0 & 10.3 & 17.6 & 88.4 \\
\hline \multirow{2}{*}{$13-18$} & $\mathrm{M}$ & 0.2 & 0.8 & 1.1 & 5.4 & 9.2 & 46.5 \\
\hline & $\mathrm{F}$ & 0.2 & 0.9 & 1.2 & 6.2 & 10.6 & 53.2 \\
\hline \multirow{2}{*}{$>19$} & $\mathrm{M}$ & 0.1 & 0.6 & 0.9 & 4.4 & 7.4 & 37.3 \\
\hline & $\mathrm{F}$ & 0.2 & 0.8 & 1.1 & 5.3 & 9.0 & 45.1 \\
\hline \multicolumn{2}{|c|}{ Average } & 0.3 & 1.3 & 1.8 & 8.9 & 15.2 & 76.3 \\
\hline
\end{tabular}




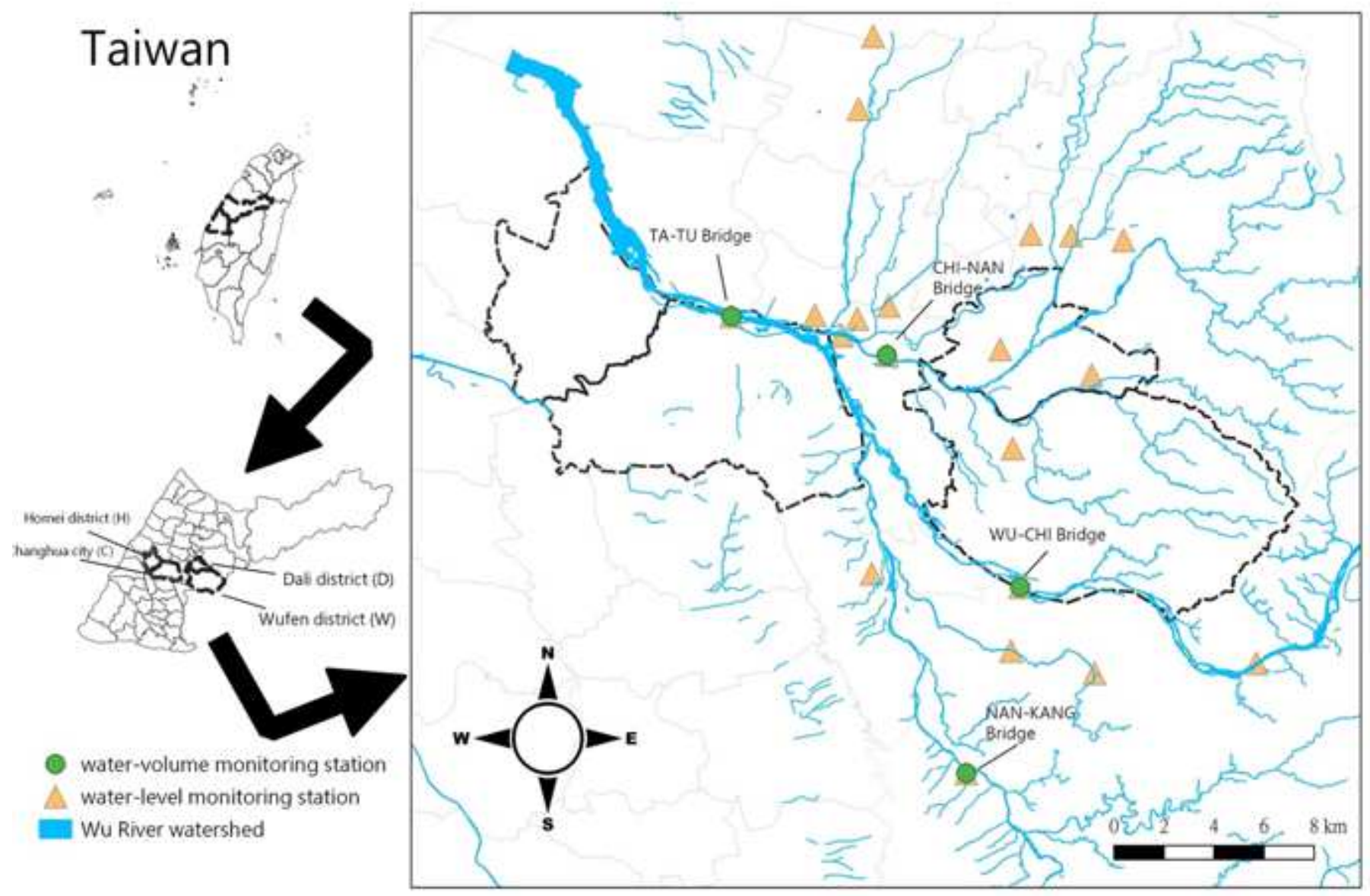

\section{Figure 1}

Locations of Changhua county, Taichung city, and the Wu River watershed. Note: The designations employed and the presentation of the material on this map do not imply the expression of any opinion whatsoever on the part of Research Square concerning the legal status of any country, territory, city or area or of its authorities, or concerning the delimitation of its frontiers or boundaries. This map has been provided by the authors. 


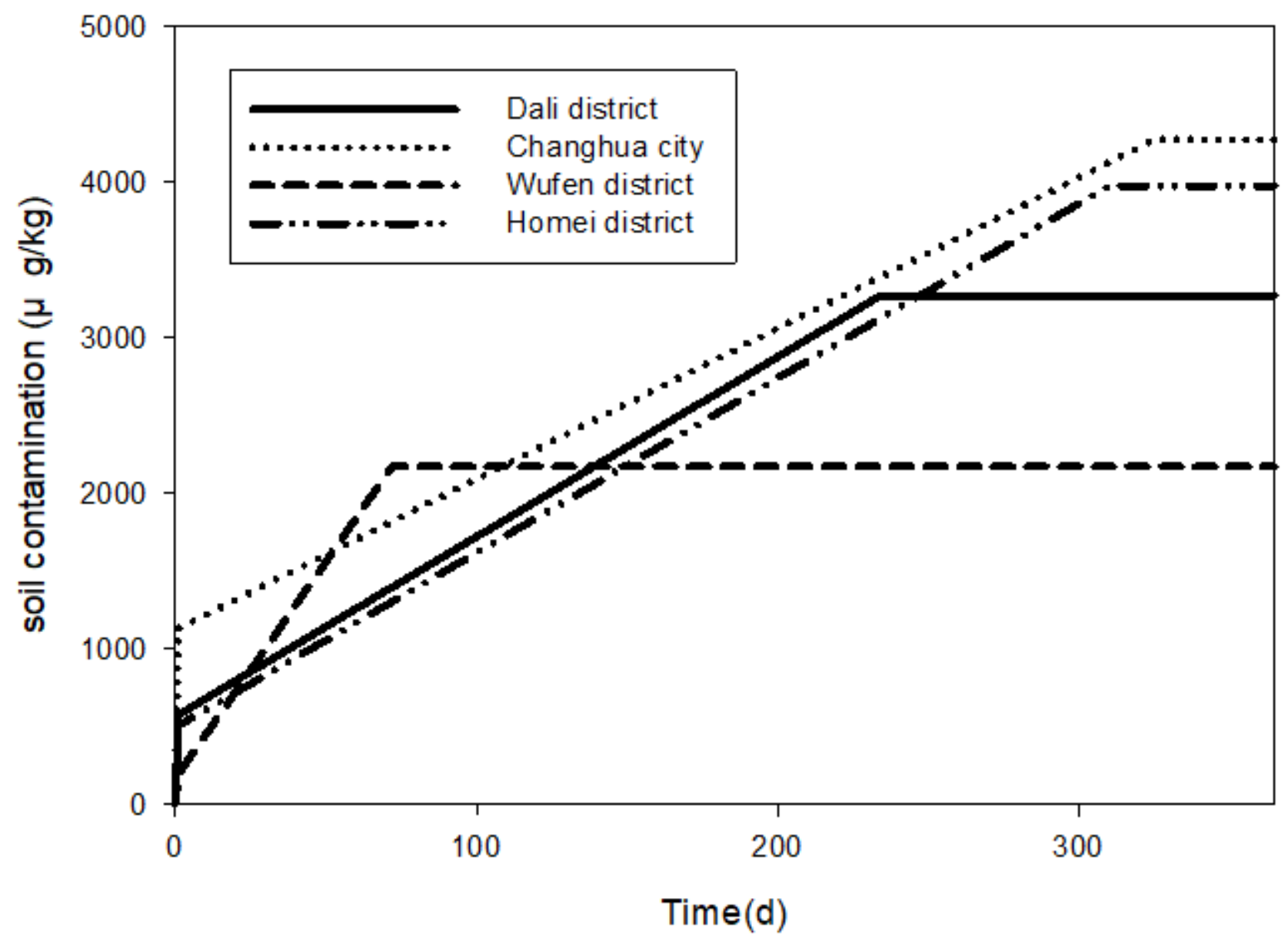

Figure 2

$\mathrm{Cr}(\mathrm{VI})$ contamination in different cities/districts simulated by the WASP model 


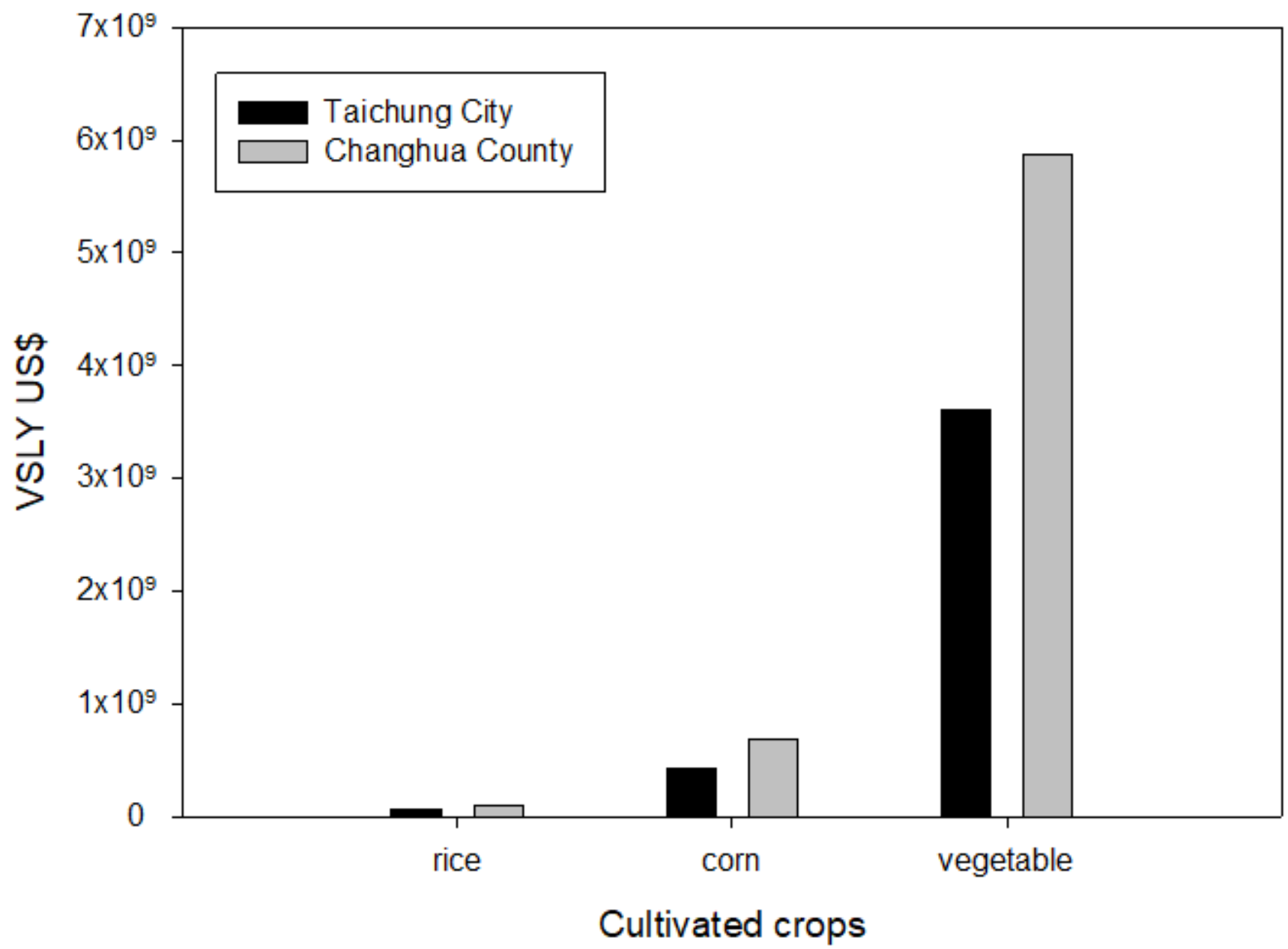

Figure 3

The VSLY results from different cultivated crops in the Taichung city and Changhua county. 


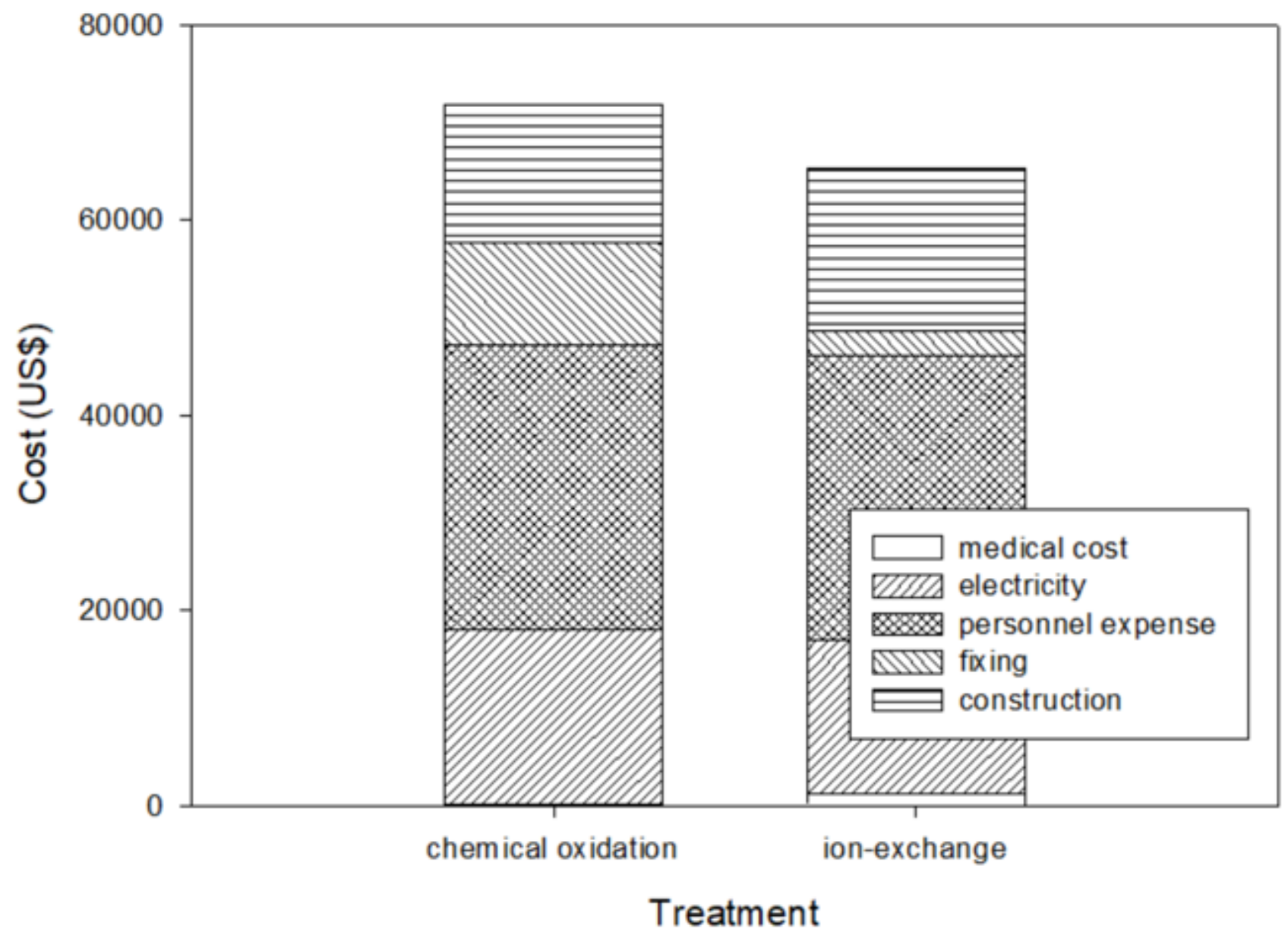

Figure 4

The pollution-prevention costs for chemical oxidation and ion-exchange treatment in the Wu River.

\section{Supplementary Files}

This is a list of supplementary files associated with this preprint. Click to download.

- WASPSupplementarymaterial.docx 